\title{
Dermatological diseases in seamen's lower extremity: a prevalence study
}

\author{
Vanesa Rego-Pena ${ }^{1} \oplus$, María Ángeles Bouza-Prego ${ }^{1} \oplus$, Fernando Gómez-Muniz² $^{\oplus}$, Raquel Veiga-Seijo $^{1} \oplus$ \\ ${ }^{1}$ University of A Coruña, A Coruña, Spain \\ ${ }^{2}$ University of San Rafael-Nebrija, Madrid, Spain
}

\begin{abstract}
Background: Little is known about the impact of occupational seafaring on lower limb conditions. The aim of the study was to estimate the prevalence of dermatological diseases affecting the feet and lower extremities of seafarers, as well as the possible impact of working conditions on the development of the pathologies analysed.

Materials and methods: A prevalence study was performed through self-completed questionnaires at the "Instituto Social de la Marina" (ISM) centres at A Coruña, Ribeira, Noya and Cádiz (Spain). Sociodemographic, anthropometric and podiatric variables, as well as the type of maritime sector, duty on board and, working footwear, were studied ( $n=137$ ). The study has been approved by the Ethics Committee of the University of A Coruña (CE 13/2016).

Results: The average age of the study subjects was $45.71 \pm 9.90$ years and the number of years sailed was $20.31 \pm 11.64$ years. The most prevalent pathologies were mycosis $(21.9 \%)$, helomas and tylomas (29.9\%) and hyperhidrosis (17.5\%). A statistically significant relationship was obtained between pruritus and scabies $(p \leq 0.000)$, xerosis $(p \leq 0.005)$, eczema $(p \leq 0.000)$, obesity $(p \leq 0.018)$ and psoriasis $(p \leq 0.005)$. A significant relationship was also found between onychocryptosis, and psoriasis $(p \leq 0.000)$. Frequency with which the study participants have visited the podiatrist was significantly related to the presence of helomas and tylomas ( $p \leq 0.013)$ and hyperhidrosis $(p \leq 0.025)$.

Conclusions: $A$ high prevalence of diverse dermatological diseases has been found, revealing the importance of podiatric assessment in sea workers prior to boarding.
\end{abstract}

(Int Marit Health 2021; 72, 1: 18-25)

Key words: foot diseases, skin diseases, sea workers, dermatology, clinical research

\section{INTRODUCTION}

It is widely known that working conditions of sea workers have a very negative effect on their health and well-being. In spite of the improvement of working conditions (protective clothing, footwear, health education), in recent decades, there are a number of risk factors associated with the job that cannot be avoided, such as working in confined spaces and on mobile platforms, exposure to harsh environmental conditions (e.g. cold weather, high humidity or extreme heat), high physical workloads, family and social isolation and distance from health care centres. The presence of the aforementioned risk factors has led to the introduction of occupational health and safety measures to protect sea workers [1]. Nevertheless, little is known about the impact of the sea work on foot and lower limb conditions; therefore it is necessary to carry out further studies from a podiatry perspective.

This study was performed to determine the prevalence of dermatological diseases in lower extremities of sea workers, as well as the possible relationship among the analysed diseases. We have studied the potential relationship between the pathologies identified and the age of study participants,

Raquel Veiga-Seijo, PhD student in Health Sciences, Faculty of Health Sciences. University of A Coruña, Spain, e-mail: raquel.veiga.seijo@udc.es 
Table 1. Descriptive analysis of the sociodemographic variables

\begin{tabular}{lllll}
\hline & Mean \pm SD & Median & Maximum & Minimum \\
\hline Age $[$ years] & $45.71 \pm 9.90$ & 47 & 66 & 22 \\
Weight $[\mathrm{kg}]$ & $81.13 \pm 14.78$ & 80 & 126 & 55 \\
Size $[\mathrm{m}]$ & $1.72 \pm 0.07$ & 1.73 & 1.90 & 1.48 \\
BMl $\left[\mathrm{kg} / \mathrm{m}^{2}\right]$ & $27.15 \pm 4.33$ & 26.23 & 42.59 & 18.95 \\
Sailing years & $20.31 \pm 11.64$ & 20 & 47 & 1
\end{tabular}

$\mathrm{BMI}$ - body mass index; SD - standard deviation

their body mass index (BMI), years of service, type of ship, the number of pathologies and whether or not they have received treatment.

\section{MATERIALS AND METHODS}

A descriptive study of prevalence was carried out.

Data collection was performed through self-completed questionnaires delivered to workers in "Instituto Social de la Marina” (ISM) centres at A Coruña, Noya, Ribeira and Cádiz, which are representative concerning seafarers' population in Spain. The data were collected in April and May 2017 and were then analysed before the end of 2017.

The study included only those workers who passed the medical check-up previous embankment in the selected centres and provided written informed consent prior to data collection (they agreed to participate in the study voluntarily), were all adults (> 18 years) and were working at sea th the time of study performance (either in the fishing or merchant sector).

The questionnaire was delivered by the doctor when workers were going to do the medical test. This medical test was performed prior to shipment. When participants returned to the doctor to know the results of the medical check-up, they could submit the completed questionnaires. The participants were informed that they could only cover in the questionnaire the diseases that had been previously diagnosed by a health professional.

The variables studied included: sociodemographic variables (age and gender), anthropometric variables (weight in kilograms, height in centimetres and BMI [2]), maritime sector in which the study participants worked (fishing or merchant fleet), duty on board (officer, deck, etc.), working footwear, pathology (location, treatment and progression) and the frequency with which they visit a podiatrist.

Dermatological conditions studied have been selected in line with the tenth revision of the International Statistical Classification of Diseases and Morbid States criteria and the International Classification of Diseases [3, 4].

In relation to the ethical-legal aspects, the Ethics Committee of the University of A Coruña approved the study project (EC 13/2016). At a local level, the Provincial Direc- torate of ISM at A Coruña, was requested to distribute the questionnaires to the ISM centres in the cities of A Coruña, Noya and Ferrol, and to the provincial directorate of the ISM of Villagarcía for the centre of Ribeira; ISM at Cadiz was also asked to collaborate.

Although the questionnaires were anonymous, the participants were asked for informed consent, which stated that all data would be used for research purposes only and in accordance with the Valid Data Protection Act [5].

Regarding the sample size, 137 subjects have been studied, which allowed us to estimate the parameters of interest with a confidence interval of $95 \%$, a precision of $\pm 4 \%$ and a risk $\alpha=0.05$.

\section{STATISTICAL ANALYSIS}

A descriptive analysis of the variables included in the study has been carried out. To relate the different variables to each other, the $\chi^{2}$ or $t$ Student test has been used. P-value of less than 0.05 was considered statistically significant. Data analysis was performed using the IBM SPSS 21 statistical package for Windows.

\section{RESULTS}

Description of the sociodemographic variables analysed in the study is shown in Table 1. A total of 137 workers have been studied, of which $92 \%$ were men and $8 \%$ were women.

The average age of the study participants was $45.71 \pm$ \pm 9.90 years with the minimum age of 22 years and the maximum age of 66 years.

Following the criteria of the Spanish Society for the Study of Obesity (SEEDO) [2], we have estimated that $34.1 \%$ of subjects had normal body weight, $42.0 \%$ were overweight and $23.9 \%$ had obesity.

In relation terms of the type of vessel on which they were employed, $25.5 \%$ of individuals worked in Merchant Navy, $40.1 \%$ in high fishing, $26.3 \%$ in coastal fishing and $8 \%$ served on various types of vessels throughout their working life.

Wearing special working footwear was declared by $92.7 \%$ of the workers. Regarding the type of footwear used, 51\% used half-leg rubber boots and $41.6 \%$ used safety boots. 
Table 2. Descriptive analysis of dermal and ungual diseases of the foot studied

\begin{tabular}{|c|c|c|c|c|}
\hline & \multicolumn{2}{|c|}{ Yes } & \multicolumn{2}{|l|}{ No } \\
\hline & $\mathbf{N}$ & $\%$ & $\mathbf{N}$ & $\%$ \\
\hline Contact dermatitis & 1 & $0.7 \%$ & 136 & $99.3 \%$ \\
\hline Allergic dermatitis & 3 & $2.2 \%$ & 134 & $97.8 \%$ \\
\hline Eczema & 4 & $3 \%$ & 137 & $97 \%$ \\
\hline Pruritus & 14 & $11 \%$ & 123 & $89.8 \%$ \\
\hline Mycosis & 30 & $21.9 \%$ & 107 & $78.1 \%$ \\
\hline Scabies & 2 & $1.5 \%$ & 135 & $98.5 \%$ \\
\hline Moluscum contagiosum & 0 & $0 \%$ & 137 & $100 \%$ \\
\hline Onychomycosis & 9 & $6.5 \%$ & 128 & $92.8 \%$ \\
\hline Warts & 7 & $5.1 \%$ & 130 & $94.9 \%$ \\
\hline Plantar warts & 5 & $3.6 \%$ & 137 & $96.4 \%$ \\
\hline Cellulitis & 3 & $2.2 \%$ & 134 & $97.8 \%$ \\
\hline Boil & 5 & $3.6 \%$ & 132 & $96.4 \%$ \\
\hline Onychopathy & 12 & $8.8 \%$ & 125 & $91.2 \%$ \\
\hline Onychocryptosis & 6 & $4.4 \%$ & 131 & $95.6 \%$ \\
\hline Helomas and tylomas & 41 & $29.9 \%$ & 96 & $70.1 \%$ \\
\hline Xerosis & 22 & $16 \%$ & 115 & $83.9 \%$ \\
\hline Moles & 3 & $2.2 \%$ & 134 & $97.8 \%$ \\
\hline Varicose ulcers & 8 & $5.8 \%$ & 129 & $94.2 \%$ \\
\hline Hyperhidrosis & 24 & $17.5 \%$ & 113 & $81.9 \%$ \\
\hline Pink pityriasis & 1 & $0.7 \%$ & 136 & $98.6 \%$ \\
\hline Stings & 10 & $7.2 \%$ & 127 & $92 \%$ \\
\hline Others & 6 & $4.3 \%$ & 131 & $96.2 \%$ \\
\hline
\end{tabular}

As regards the question on the frequency of podiatry consultation, only 6 (4.4\%) workers reported that they have often consulted a podiatrist, 26 (19\%) subjects sometimes consulted a podiatrist and the vast majority - 105 (76\%) subjects have never had a podiatric consultation.

Table 2 shows the descriptive analysis of the dermal and ungual conditions of the foot which have been studied.

As can be seen in the Table 2, the most frequent pathologies have been helomas and tylomas, 41 (29.9\%) cases, mycosis, 30 (21.9\%) cases, and hyperhidrosis, 24 (17.5\%) cases. Note that no cases of molluscum contagiosum have been identified.

The location of the pathologies discussed in the study can be seen in Table 3. One of the significant findings was that scabies often involved the feet and legs, which leads to a conclusion that the lesions have not been treated.

Table 4 shows the number of individuals who have or have not received podiatric treatment (including those who might have received treatment but failed to report the fact).

It must be underlined that despite a high prevalence of helomas and tylomas, mycosis and hyperhidrosis, the results show that only $34.2 \%$ of workers with helomas and tylomas, $37.5 \%$ of those with hyperhidrosis and $63.4 \%$ with mycosis, have been treated. In contrast, rare pathologies such as cellulite have been treated in $100 \%$ of cases. If the total number of workers is considered, regardless the pathology they suffered, it was found that only $16 \%$ have been treated or were being treated.

On the other hand, when the relationship between non-dermatological and dermatological variables is studied, the results are as follows:

- sailing years vs. the presence of varicose ulcers $(p<0.021)$ and hyperhidrosis $(p \leq 0.040)$;

- type of ship vs. eczema ( $p \leq 0.001)$ and onychocryptosis ( $p \leq 0.001)$; 
Table 3. Location of disease

\begin{tabular}{|c|c|c|c|}
\hline & Location & $\mathbf{N}$ & $\%$ \\
\hline Contact dermatitis & Legs & 1 & $0.7 \%$ \\
\hline Allergic dermatitis & $\begin{array}{l}\text { Legs } \\
\text { Ambos }\end{array}$ & $\begin{array}{l}1 \\
2\end{array}$ & $\begin{array}{l}0.7 \% \\
1.5 \%\end{array}$ \\
\hline Eczema & $\begin{array}{l}\text { Legs } \\
\text { Ambos }\end{array}$ & $\begin{array}{l}2 \\
2\end{array}$ & $\begin{array}{l}1.5 \% \\
1.5 \%\end{array}$ \\
\hline Pruritus & $\begin{array}{l}\text { Legs } \\
\text { Feet } \\
\text { Legs and feet }\end{array}$ & $\begin{array}{l}3 \\
6 \\
5\end{array}$ & $\begin{array}{l}2.2 \% \\
4.4 \% \\
3.6 \%\end{array}$ \\
\hline Mycosis & $\begin{array}{l}\text { Legs } \\
\text { Feet }\end{array}$ & $\begin{array}{l}3 \\
27\end{array}$ & $\begin{array}{l}2.2 \% \\
19.7 \%\end{array}$ \\
\hline Scabies & Legs and feet & 2 & $1.5 \%$ \\
\hline Onychomycosis & Feet & 9 & $6.6 \%$ \\
\hline Warts & Legs & 7 & $5.1 \%$ \\
\hline Plantar warts & Feet & 5 & $3.6 \%$ \\
\hline Cellulitis & $\begin{array}{l}\text { Legs } \\
\text { Legs and feet }\end{array}$ & $\begin{array}{l}2 \\
1\end{array}$ & $\begin{array}{l}1.5 \% \\
0.7 \%\end{array}$ \\
\hline Boil & Legs & 5 & $3.6 \%$ \\
\hline Onychopathy & Feet & 12 & $8.7 \%$ \\
\hline Onychocryptosis & Feet & 6 & $4.4 \%$ \\
\hline Helomas and tylomas & Feet & 41 & $29.9 \%$ \\
\hline Xerosis & $\begin{array}{l}\text { Legs } \\
\text { Feet } \\
\text { Legs and feet }\end{array}$ & $\begin{array}{l}4 \\
5 \\
13\end{array}$ & $\begin{array}{l}2.9 \% \\
3.6 \% \\
9.5 \%\end{array}$ \\
\hline Moles & $\begin{array}{l}\text { Feet } \\
\text { Legs }\end{array}$ & $\begin{array}{l}1 \\
2\end{array}$ & $\begin{array}{l}0.7 \% \\
1.5 \%\end{array}$ \\
\hline Varicose ulcers & Legs & 8 & $5.8 \%$ \\
\hline Hyperhidrosis & Feet & 24 & $17.5 \%$ \\
\hline Pink pityriasis & Legs and feet & 1 & $0.7 \%$ \\
\hline Stings & $\begin{array}{l}\text { Legs } \\
\text { Legs and feet }\end{array}$ & $\begin{array}{l}6 \\
4\end{array}$ & $\begin{array}{l}4.4 \% \\
2.9 \%\end{array}$ \\
\hline Others & $\begin{array}{l}\text { Hidradenitis } \\
\text { Psoriasis } \\
\text { Varicose veins }\end{array}$ & $\begin{array}{l}1 \\
4 \\
1\end{array}$ & $\begin{array}{l}0.7 \% \\
2.9 \% \\
0.7 \%\end{array}$ \\
\hline
\end{tabular}

- increased incidence of helomas and tylomas vs. rare podiatrist consultations $(p=0.013)$;

- hyperhidrosis vs. rare podiatrist consultations $(p \leq 0.025)$;

- boils vs. obesity $(p \leq 0.011)$;

- obesity vs. pruritus $(p \leq 0.018)$.

According to the available literature, there is a statistically significant relationship among some of the pathologies studied. The same relationships have been identified in the current study; we have found the following:

- the presence of pruritus is significantly associated with scabies $(p \leq 0.000)$, xerosis $(p=0.005)$, eczema $(p \leq 0.000)$, and psoriasis $(p \leq 0.005)$;

- the presence of psoriasis is significantly associated with onychocryptosis $(p=0.000)$, xerosis $(p \leq 0.047)$, and eczema ( $p \leq 0.000)$;

- BMI falling within the obesity range is significantly related with the presence of boils $(p \leq 0.011)$ and mycosis $(p \leq 0.18)[5]$.

Regarding the number of pathologies affecting individual subjects throughout their working life (sample size 137 subjects), 45 (32.6\%) have not reported any of the pathologies raised in this study. However, 93 (67.8\%) subjects have experienced some type of pathology affecting the lower limb; 57 (61.2\%) have experienced at least two pathologies compared to the remaining $38.8 \%$ (36 people) who only manifest at the time of the study or manifested in the past a pathology.

It is worth mentioning that one seaman who has had 8 different pathologies throughout his working life.

Finally, note that of the 93 people who reported the presence of the lower limb pathologies, 58 (62.3\%) still have the medical condition they have reported, and only 29 (37.6\%) have been successfully treated.

\section{DISCUSSION}

This study is one of a few on the subject carried out in the maritime sector at a national level; therefore, little information and limited bibliography is available.

The discussion part of the article evaluates concordance of the results we have obtained with study findings by other researchers on the same subject.

- Contact dermatitis [6-8]: Contact dermatitis affects $1.3 \%$ of the population of the United States. The present study has found the prevalence of contact dermatitis to be $0.7 \%$; this lower rate could be associated with the mandatory use of protective measures at work [9-11], leaving other body parts not included in the present investigation more exposed.

- Allergic dermatitis: Recent studies have shown that the prevalence of allergic dermatitis in different regions of Europe is around 1\% [12]. This study has demonstrated the prevalence of $2.2 \%$, possibly due to more common exposure to irritants, limited use of appropriate prevention measures and, in some cases, contact with marine animals [13].

- Eczema: The present study found that the prevalence of eczema was 3\%, and we have not found any other similar studies into the prevalence of eczema in adults [14]. We have identified a direct relationship between the presence of eczema and pruritus $(p \leq 0.000)$ (pruritus is considered one of the symptoms of eczema $[14,15])$ as well as psoriasis $(p \leq 0.000)$. Our findings are similar to the results of several other studies in this respect.

- Pruritus: Pruritus can be attributed to several dermatological causes, such as atopic dermatitis, contact 
Table 4. Diseases and treatment

\begin{tabular}{|c|c|c|c|c|c|}
\hline & Diagnosis (n) & No treated (n) & Treated (n) & Treatment & $\begin{array}{l}\text { Do not know, } \\
\text { no answer (n) }\end{array}$ \\
\hline Contact dermatitis & 1 & 1 & & & \\
\hline Allergic dermatitis & 3 & 1 & 1 & Corticoid & 1 \\
\hline Eczema & 4 & 3 & & & 1 \\
\hline Pruritus & 14 & 12 & & & 2 \\
\hline Mycosis & 30 & 11 & 9 & Antifungal & 10 \\
\hline Scabies & 2 & & 1 & Antiparasitic & 1 \\
\hline Onychomycosis & 9 & 6 & & & 3 \\
\hline Warts & 7 & 4 & 2 & Surgery, cryotherapy & 1 \\
\hline Plantar warts & 5 & 1 & & & 4 \\
\hline Cellulitis & 3 & & 2 & Antibiotic & 1 \\
\hline Boil & 5 & 1 & 2 & Antibiotic & 3 \\
\hline Onychopathy & 12 & 9 & 1 & Chiropody & 2 \\
\hline Onychocryptosis & 6 & 2 & 1 & Chiropody & 3 \\
\hline $\begin{array}{l}\text { Hyperkeratosis and } \\
\text { helomas }\end{array}$ & 41 & 27 & 9 & $\begin{array}{l}\text { Chiropody, plantar } \\
\text { orthosis and surgery }\end{array}$ & 5 \\
\hline Xerosis & 22 & 9 & 11 & Emollient & 2 \\
\hline Moles & 3 & & 3 & Surgery, cryotherapy & \\
\hline Varicose ulcers & 8 & 5 & 1 & Surgery & 2 \\
\hline Hyperhidrosis & 24 & 15 & 4 & Antifungal, astringent & 5 \\
\hline Pink pityriasis & 1 & 1 & & & \\
\hline Stings & 10 & 7 & 2 & Corticoid & 1 \\
\hline Others & 6 & 3 & & & 3 \\
\hline
\end{tabular}

dermatitis, xerosis, eczema or scabies [16]. A significant relationship was found between the presence of pruritus and scabies ( $p \leq 0.000$ ), xerosis ( $p \leq 0.005)$, eczema ( $p \leq 0.000$ ), as was demonstrated in the Herade and Urbina study [16]. In addition, pruritus may be a sign of dermatological diseases such as atopic dermatitis and psoriasis; the present study has found a relationship between pruritus and psoriasis ( $p<0.005)$.

- Mycosis: The use of non-breathable footwear, extended working hours, and exposure to excess humidity at sea result in a high incidence of tinea pedis in individuals wearing occlusive footwear [17-19]; exogenous transmission of mycosis in susceptible individuals is common under the above-listed conditions [20, 21].

- The World Health Organization (WHO) states that the overall prevalence of superficial mycoses is very high, affecting between $20 \%$ and $25 \%$ of the general population, the condition is more frequent in humid climates [22]. A total of $21.9 \%$ of the subjects involved in this study reported either past or present history of mycosis, which is consistent with the WHO data.
- Scabies: Scabies, like mycosis, can be spread by direct or indirect contact through the use of common objects [23]. Although the study did not find a high prevalence of scabies among the participants (1.5\%), it should be noted that some authors have attributed a higher prevalence of scabies to high humidity (air humidity is naturally higher at sea) and warm climates (some shipping routes pass through hot climate regions).

- Onychopathies:

- Onychocryptosis: According to the consulted bibliography, onychocryptosis is significantly associated with hyperhidrosis [24]; this relationship, however, has not been confirmed by the results of this study. No significant association was found between the occurrence of onychocryptosis and the use of safety footwear, although we have identified a relationship between this pathology and psoriasis $(p \leq 0.000)$.

- Onychomycosis: The present study found that the prevalence of onychomycosis was $6.5 \%$. The findings in this respect are incompatible with the available literature $[25,26]$. 
- Warts and plantar warts: There is no available literature on the prevalence of plantar warts in adults which could serve as the basis for comparison (the prevalence of cutaneous warts in adolescents has been estimated at $0.8-22 \%)$. According to the literature consulted [27-29], low prevalence of warts and plantar warts might be attributable to stronger immunity in adults.

- Cellulite: There are no updated studies on the prevalence of cellulite in the working population [30]. The prevalence of cellulite in our study was found to be $2.2 \%$.

- Bound: Several studies [31] have suggested that obesity is associated with the increase in the prevalence of this pathology; our study findings are similar in this respect $(p \leq 0.011)$.

- Helomas and tylomas: The current study showed the prevalence of helomas and tylomas at $29.9 \%$. In older individuals [32], the prevalence was found to be $20.8 \%$; however, because of significant differences between the two populations, the comparison is not useful. The high incidence of the pathologies can be due to the use of wrong footwear and difficult working conditions, for example, standing on mobile platforms for long hours, which causes changes in foot biomechanics and static foot posture, which in turn can cause overload in different areas of the foot.

- Xerosis [33]: Xerosis was found to be one of the most prevalent diseases among the study subjects, affecting $16 \%$ of the sample. Interestingly, $40.9 \%$ of the affected workers who suffer from it are not following any treatment. The prevalence of xerosis in the elderly population is $66.7 \%$ [32], but this population group cannot be compared to our study sample because work-related xerosis could be caused by exogenous factors, whereas in the elderly it is normally age-related.

- Premalignant and malignant moles: According to the American Cancer Society [34], melanomas represent 1\% of all skin cancers. In the current study, the prevalence of premalignant and malignant moles was $2.2 \%$, which is higher than in the previously mentioned study. This higher prevalence may be due to more frequent exposure to sun radiation in this group of workers.

- Varicose ulcer: The prevalence of venous ulcers in people over 65 years is estimated at $5.6 \%$ [35]. In the current study it was found to be $5.8 \%$, of which $62.5 \%$ cases were left untreated. The explanation for a higher prevalence of varicose ulcer in the study sample may be the working conditions, i.e. working in a standing position for long hours.

- Hyperhidrosis: In the literature reviewed, we have found that the condition is present in $2.8 \%$ of the population in the United States population [36]. In comparison, we found that hyperhidrosis affected 24 of the study subjects $(17.5 \%)$, which is particularly alarming.
- Pityriasis rosea: In the literature, the prevalence of pityriasis rosea is estimated at $0.36 \%[37,38]$ in dermatological patients $[39,40]$. In the present study, only one person manifested this pathology, which represents $0.7 \%$ of the sample (a higher percentage than in the referenced studies), possibly due to the age range of the workers involved in the current study.

- Psoriasis: This pathology cannot be associated with working conditions but rather with the development of other diseases, or the occurrence of certain precipitating factors such as traumas, which are quite frequent among sea workers [41]. It affects between $0.1 \%$ and $3 \%$ of general the population [42] but our study showed a prevalence of $3 \%$, which is consistent with the data found in the literature consulted.

As for the treatment of pathologies, the results of the study show that not all cases of the more frequent pathologies, such mycosis, helomas, tylomas and hyperhidrosis, have been treated, unlike cellulitis. This may be due to the fact that the diseases mentioned in the first place are not incapacitating and do not prevent embarking, while in the case of cellulitis, due to its seriousness, a worker would be declared unfit for boarding.

In spite of this, other pathologies should not be downplayed, since they can also lead to more serious problems.

Taking into account the discussion recently presented, it is possible to objectify what has been similarly highlighted in other investigations [43-45], which is the important relationship between working conditions at sea and health problems at the skin level [45]. For this reason, these aspects have been studied for some time, although this study focuses on the podiatric level. Although there is more research, it has been observed that there is a scarcity of epidemiological studies in Latin America in contrast to other more developed countries [44].

On the other hand, the literature review developed by Jensen et al. [44] highlights the importance of doing studies about occupational health problems, giving special relevance to skin lesions, with the aim of developing prevention systems $[44,45]$.

All these aspects and the results of our study also agree with the research carried out by Loddé et al. [46], in which they state that the maritime environment constitutes a risk factor for the development of skin conditions, causing pathologies of great relevance and severity [46].

\section{LIMITATIONS OF THE STUDY}

Concerning the limitations of the study, it is necessary taking into account that weight and height are estimated by the worker himself, and therefore do not provide a reliable $\mathrm{BMI}$. This is because there is a tendency to say that we are taller and lighter than we are. 
Although the questionnaire was covered by the worker himself, the doctor who developed the medical check-up, explained them that they could only cover in the questionnaire the diseases that had been previously diagnosed by a health professional.

Regarding the healthy worker effect in our results, it is necessary to mention that only healthy seafarers can embark, so the sample studied did not present important systemic pathologies. Likewise, this study is a descriptive observational study of prevalence, in which the aim is to estimate the characteristics of the sample in relation to the objective of the study previously described.

\section{CONCLUSIONS}

As can be seen from the article, we have found that the variety and prevalence of in the study population is higher than in the general population.

It is worrisome that a large number of workers presenting with dermatological conditions do not receive appropriate treatment. Although some of these conditions are not extremely serious, they can have a negative impact on a worker's quality of life (both the condition of their feet and their general condition).

If we add to the above that a vast majority of the sea workers have never had a podiatrist consultation and that there is no podiatric assessment protocol when performing the medical examinations prior to boarding, we consider that it would be necessary to include the podiatric consultation in the said occupational fitness assessments.

Due to an increased incidence of premalignant and malignant moles, it would be advisable to conduct awareness campaigns among sea workers to remind them of the necessity to periodically check their lower limbs for any newly appearing or changing moles.

\section{CONFLICT OF INTEREST AND SOURCES OF FUNDING}

The authors certify that there is no conflict of interest with any financial organization regarding the material discussed in the manuscript.

This research does not have any source of funding.

\section{REFERENCES}

1. Real Decreto $1696 / 2007$, de 14 de diciembre, por el que se regulan los reconocimientos médicos de embarque marítimo. BOE [Internet]. https://www.boe.es/diario_boe/txt.php?id=BOE-A-2007-22533 (2007 Dic 31, [reviewed 2016 Mar 27; quoted 2018 May 31];(313):11p. [Spanish]).

2. Salas-Salvadó J, Rubio M, Barbany M, et al. Consenso SEEDO 2007 para la evaluación del sobrepeso y la obesidad y el establecimiento de criterios de intervención terapéutica. Medicina Clínica. 2007; 128(5): 184-196, doi: 10.1016/s0025-7753(07)72531-9.

3. Clasificación Estadística Internacional de Enfermedades Décima Revisión. Organización Panamericana de la Salud, Publicación científica [Internet]. (Washington DC): 1995. https://iris.paho.org/ bitstream/handle/10665.2/6282/Volume1.pdf (2018 Mar 15).
4. Ministerio de Sanidad, Política Social e Igualdad. Clasificación Internacional de Enfermedades 9 Revisión Modificación Clínica (CIE-9). Secretaría General Técnica. Ministerio de Sanidad, Política Social e Igualdad; 2012 [Spanish].

5. Reglamento General de Protección de datos, de mayo de 2016, de la normativa europea de protección de datos. Diario oficial de la Unión Europea. https://www.boe.es/doue/2016/119/L0000100088.pdf (27/04/2016).

6. García-Gavín J, Armario-Hita JC, Fernández-Redondo V, et al. Epidemiología del eczema de contacto en España. Resultados de la Red Española de Vigilancia en Alergia de Contacto (REVAC) durante el año 2008. Actas Dermo-Sifiliográficas. 2011; 102(2): 98-105, doi: 10.1016/j.ad.2010.10.015.

7. Paz-Castanedo M, Zug K. F. Dermatología en Medicina General [Spanish]. 8aed. Madrid. Editorial Médica Panamericana; 2013. Sección 4.Trastornos inflamatorios basados en la reactividad y la desregulación de los linfocitos T, Dermatitis alérgica por contacto; p.152-164 [Spanish].

8. Johnson MD, Marie-Louise T. Skin Conditions and Related Need for Medical Care among Persons 1-74 Years [thesis in Internet]. Hyattsville, Md: US, Department of health, Education and Welfare;1978. https://www.cdc.gov/nchs/data/series/sr_11/sr11_212. pdf (2018 May 31).

9. Ley $31 / 1995$, de 8 de noviembre, de prevención de Riesgos Laborales. BOE [Internet]. https://www.boe.es/buscar/doc.php?id=BOE-A-1995-24292 (1995 Nov 10 [reviewed 2016 Mar 27; quoted 2018 May 31]; (269): 22p).

10. Organización Marítima Internacional (OMI) [Internet]. Convenio internacional sobre normas de formación, titulación y guardia para la gente de mar (España): Organización Marítima Internacional (OMI), 2016. http://www.imo.org/es/ (2018 May 31).

11. International Labour Organization. Título 4. Protección de la salud, atención médica, bienestar y protección social en su regla 4.1 "Atención médica a bordo de buques y en tierra". En: Convenio Internacional sobre el Trabajo Marítimo 2006. Ginebra; 2006 [Spanish].

12. Diepgen TL, Ofenloch RF, Bruze M, et al. Prevalence of contact allergy in the general population in different European regions. $\mathrm{Br}$ J Dermatol. 2016; 174(2): 319-329, doi: 10.1111/bjd.14167, indexed in Pubmed: 26370659.

13. Nogueroles Alonso de la Siera PJ, Zafra Mezcua JA. Patología del trabajo y su prevención: Sector marítimo-pesquero [Spanish]. Protección Laboral. 2002; 30: 42-45.

14. Tatto Cano M, Sanín Aguirre L, Gonzalez V, et al. Prevalencia de asma, rinitis y eczema en escolares de la ciudad de Cuernavaca, México. Salud Pública de México. 1997; 39(6): 497-506, doi: 10.1590/s0036-36341997000600002.

15. Hoare C, Li Wan Po A, Williams H. Systematic review of treatments for atopic eczema. Health Technol Assess. 2001; 4(37): 1-191, indexed in Pubmed: 11134919.

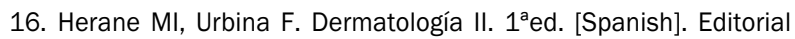
Mediterráneo, Santiago de Chile. 2001.

17. Rubio Fernandez, G. Aproximación a la calzadoterapia en la sociedad actual [Trabajo Fin de Grado]. Ferrol: Universidade da Coruña; 2013 [Spanish].

18. Álvarez-Calderón Iglesias O, Alonso Tajes F, López López D, et al. Análisis del calzado en una población mayor de 60 años. Rev Internac Cienc Podolog. 2008; 2(1): 19-26.

19. Fernández MM. Calzado laboral y actuación podológica. Revista Internacional de Ciencias Podológicas. 2011; 5(1), doi: 10.5209/ rev_ricp.2011.v5.n1.19427. 
20. Pereira M. Dermatología I. $1^{\mathrm{a}}$ ed. Capítulo 4: Micosis superficiales, Tiñas. Editorial Mediterráneo, Santiago de Chile 200: 35.

21. Ortiz González L. Prevalencia de micosis en los pies en deportistas de fútbol y baloncesto. Rev Español Podolog. 2014; 25(3): 82-85.

22. Sánchez Saldaña L, Matos Sánchez R, Kumakawa Sena H. Infecciones micóticas superficiales. Dermatol Peruana. 2009; 19(3): 226-266.

23. Díaz-Maroto Muñoz S. Sarna y sarna Noruega: Diagnóstico, prevención y tratamientos actuales. Farm Hosp. 1998; 22(1): 1-9.

24. Tosti A, Piraccini BMK. Fitzpatrick Dermatología en Medicina General. $8^{\mathrm{a} e d .}$ Editorial Médica Panamericana, Madrid 2013.

25. Vilar CM, Fernández AM, Sánchez BM. Estudio observacional y descriptivo de prevalencia de onicomicosis en una población que acude a una consulta de dermatología del Área Sanitaria de Ferrol. Revista Internacional de Ciencias Podológicas. 2015; 9(2): 89-98, doi: 10.5209/rev_ricp.2015.v9.n2.49019.

26. Zalacaín Vicuña AJ. Infeciones micóticas más frecuentes en el pie. Rev Español Podolog. 2010; 21(6): 225-229.

27. Arenas R. Verrugas virales. Atlas dermatología. $3^{a}$ ed. Mc Graw Hill, Spanish : 656-559.

28. Martínez Nova A, Sánchez Rodríguez R. Verrugas plantares. Diagnóstico y alternativas de tratamiento. Podolog Clínic. 2007; 8(3): 88-101.

29. Revenga Arranz F, Paricio Rubio JF. Las verrugas. Medicina Integral. 2001; 37(9): 395-403.

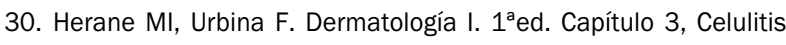
aguda. Editorial Mediterráneo, Santiago de Chile 2000: 32.

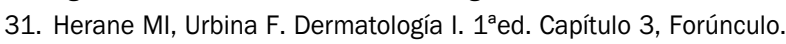
Editorial Mediterráneo, Santiago de Chile 2000: 31.

32. López Abad S, Mosquera Fernández A, Monteagudo Sánchez B. Prevalencia de patología cutánea y ungueal en una muestra poblacional de un centro de la tercera edad de la provincia de A Coruña. Enferm Dermatol. 2014; 8(23): 15-21.

33. Goldsmith L, Katz S, Gilchrest B, Paller A, Leffell D, Wolff K. Fitzpatrick Dermatología en Medicina General. $8^{\mathrm{a} e d}$. Editorial Médica Panamericana, Madrid 2013.

34. American Cancer Society. ¿Cuáles son las estadísticas principales del cáncer de piel tipo melanoma? [Internet]. 2016. https://www. cancer.org/es/cancer/cancer-de-piel-tipo-melanoma/acerca/estadisticas-clave.html (2018 May 31).
35. Raña Lama CD. Terapia compresiva en úlceras varicosas en la práctica clínica [Thesis]. RUC: Repositoria de la Universidad de Coruña; 2015 [Spanish].

36. Iannitti T, Palmieri B, Aspiro A, et al. A preliminary study of painless and effective transdermal botulinum toxin A delivery by jet nebulization for treatment of primary hyperhidrosis. Drug Des Devel Ther. 2014; 8: 931-935, doi: 10.2147/DDDT.S60389, indexed in Pubmed: 25075176.

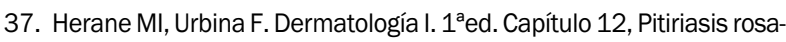
da de Gibert. Editorial Mediterráneo, Santiago de Chile 2000: 67-68.

38. Blauvelt A. Fitzpatrick Dermatología en Medicina General. $8^{\mathrm{a} e d .}$ Sección 6. Enfermedades inflamatorias basadas en la reactividad humoral anormal y otras enfermedades. Pitiriasis rosada. Editorial Médica Panamericana, Madrid 2013: 458.

39. López-Carrera I, Sáez-de-Ocariz MM. Pitiriasis rosada: un exantema que debe ser reconocido por el médico de primer contacto. Estudio de 30 casos. Acta Pediátrica de México. 2014; 35(4): 289, doi: 10.18233/apm35no4pp289-294.

40. Centeno A, Danielo C, Papa M, et al. Pitiriasis rosada atípica. Med Cutan Iber Lat Am. 2007; 35(2): 104-106.

41. Herane MI, Urbina F. Dermatología I. $1^{\mathrm{a} e d .}$ Capítulo 11, Psoriasis. Editorial Mediterráneo, Santiago de Chile 200: 63-66.

42. Gudjonsson J, Elder J. Fitzpatrick Dermatología en Medicina General. $8^{a}$ ed. Sección 4. Trastornos inflamatorios basados en la reactividad y la desregulación de los linfocitos T, Psoriasis. Editorial Médica Panamericana, Madrid 2013: 197.

43. Misery L. Maritime dermatology. Int Marit Health. 2008; 59(1-4): 113-115, indexed in Pubmed: 19227744.

44. Jensen 0, Flores A, Bygvraa DA, et al. A review of epidemiological studies in Latin American fishing. J Agromedicine. 2019; 24(4): 341-350, doi: 10.1080/1059924X.2019.1639575, indexed in Pubmed: 31293219.

45. Loddé B, Mahé C, Jacolot L, et al. Skin diseases affecting high-level competition sailors: descriptive study carried out during the 2012 AG2R transatlantic boat race. Wilderness Environ Med. 2016; 27(1): 39-45, doi: 10.1016/j.wem.2015.10.011, indexed in Pubmed: 26948552.

46. Loddé B, Pougnet R, Roguedas-Contios AM, et al. Skin infection by staphylococcus aureus in a fisherman: difficulty in continuing work on board. Int Marit Health. 2013; 64(3): 126-128, indexed in Pubmed: 24072538. 